\title{
DIAKRONIKA
}

Vol. 17 No. 2 Th. 2017 p: 142-152

ISSN: 1411-1764 (Print) | 2620-9446 (Online)

http://diakronika.ppj.unp.ac.id

\section{Menumbuhkan Pendidikan Karakter Melalui Pendalaman Materi Sejarah Peminatan Kelas X Sma}

\author{
Setya Ningsih \\ Setyaningsih12A@gmail.com \\ SMAN 1 Timpeh, Kabupaten Dharmasraya
}

\begin{abstract}
Abstrack
This article draws attention to foster characters' core values through deepening historical understanding among senior high students grade $X$. This is motivated by degradation of moral values among today youths that shows a portrait of a morality of nations as well as a morality of individuals. The dynamics of connections between space and time do not experience any significant differences in quality. Furthermore, historical values are not a guide to life but merely rhetoric, rote facts and very dry concepts and ultimately undermine the constructions of national identity and self-identity. Efforts to instil the values of glory at levels of education in high school become the fundamnetal hope of applying the national character of the nation commenced since primary educational stage. The present study is conducted at SMAN 1 Timpeh by using analytical descriptive method through observation and various important literature of reading sources. Most importantly, efforts to build the national characters among the youths in grade $X$ through learning history is expected to generate learners who always respect space and time, responsible for all decisions taken and being responsive. In this regard, a responsive and proactive attitude in learning history can make the students into smart learners. They can come up with innovative ideas that can engage and contribute to the advancement of the nation state. As well, basic competences in account of analysing history as events, stories, science and art can hopefully train students to apply discipline and responsibility. In turn, basic competences to demonstrate respect toward the national culture and tolerant will shape the identity and personality of students. With regard to this issue, teachers play the main figures of exemplary for students. Character values can be instilled by imitating the teachers' characte
\end{abstract}

Abstrak

Kajian ini bertujuan untuk menumbuhkan nilai-nilai karakter melalui pendalaman materi sejarah peminatan kelas X SMA. Hal ini dilatar belakangi oleh degradasi moral generasi muda yang menunjukkan potret kemuraman akhlak anak bangsa. Dinamika koneksi antara ruang dan waktu tidak menunjukkan kualitas yang signifikan. Nilai-nilai sejarah tidak dijadikan pedoman untuk hidup melainkan hanyalah retorika belaka, hafalan fakta dan konsep yang sangat kering dan pada akhirnya melemahkan jati diri dan identitas bangsa. Upaya menanamkan nilai-nilai kemuliaan pada jenjang pendidikan SMA menjadi harapan penerapan karakter bangsa yang sudah dimulai di jenjang pendidikan dasar. Penelitian ini dilakukan di 
SMAN 1 Timpeh dengan menggunakan metode deskriptif analitis melalui observasi dan berbagai kajian bacaan sumber (literatur). Upaya membangun karakter anak bangsa melalui pembelajaran sejarah kelas $X$ diharapkan dapat menghasilkan pribadi yang selalu menghargai ruang dan waktu, bertanggungjawab terhadap segala keputusan yang diambil dan bersikap responsif. Sikap responsif dan proaktif dalam belajar sejarah dapat membuat siswa menjadi pribadi yang cerdas. Siswa dapat memunculkan gagasan-gagasan yang inovatif sehingga mampu terlibat dan memiliki andil dalam memajukan bangsa dan negara. Kompetensi Dasar menganalisis sejarah sebagai peristiwa, kisah, ilmu dan seni diharapan dapat melatih siswa untuk berlaku disiplin dan tanggungjawab. Kompetensi Dasar menghargai peradaban budaya bangsa dan toleran akan membentuk identitas dan kepribadian siswa. Guru adalah sosok utama ketauladanan bagi siswa. Nilai-nilai karakter dapat ditanamkan dengan meneladani guru yang berkarakter.

(c) (i) (2) This work is licensed under the Creative Commons Attribution-Share Alike EY SA 4.0 International License.

\section{Pendahuluan}

Pendidikan adalah daya upaya untuk memajukan bertumbuhnya budi pekerti (kekuatan batin dan karakter), pikiran (intelek) dan tubuh anak dalam rangka kesempurnaan hidup dan keselarasan di dunianya. Pendidikan juga merupakan proses pembudayaan berupa usaha memberikan nilai-nilai luhur kepada generasi muda dalam masyarakat yang tidak hanya bersifat pemeliharaan tetapi dengan maksud memajukan serta mengembangkan kebudayaan menuju arah keluhuran hidup manusia. Pendidikan dan pengajaran idealnya memerdekakan manusia secara lahiriah dan batiniah selalu relevan untuk segala zaman (Ki Hajar Dewantara, 1962).

Degradasi moral generasi muda bangsa menjadi potret kemuraman dunia pendidikan. Dinamika koneksi antara ruang dan waktu tidak menunjukkan kualitas yang signifikan. Nilai-nilai sejarah seharusnya menjadi pijakan untuk membentuk karakter bangsa telah tergeser. Salah satu adab yang kerap dilupakan pelajar adalah sikap jujur dan amanah dalam mendapatkan ilmu yang bernilai berkah. Semangat kejujuran siswa belum tertanam dalam dirinya. Hal ini disebabkan oleh kurangnya rasa percaya diri dalam menghadapi ujian. Mereka lebih percaya jika menerima kunci jawaban dari teman, bertanya kepada teman dan percaya pada jimat (catatan contekan). Siswa seharusnya memiliki persiapan maksimal dan memiliki rasa percaya diri dan optimis bahwa jawaban yang ditulisnya adalah benar.

Siswa kurang memiliki rasa ingin tahu terhadap sesuatu hal yang membuat dirinya lebih semangat dalam belajar menunjukkan ketidakpedulian mereka terhadap dirinya sendiri. Disamping itu jika dilihat kepedulian terhadap lingkungan sosial, banyak ditemukan siswa yang kurang peduli terhadap sesama. Pergaulan mereka rusak, ditandai dengan perilaku pergaulan bebas, 
kekerasan (Bullying). Siswa tidak saling menghargai dan toleran. Ini merupakan dampak negatif dari perkembangan media digital. Siswa tidak lagi mengagungkan nilai sopan santun dalam bergaul. Banyak siswa menganggap orang yang lebih tua itu sejajar dengannya meskipun kita sudah hidup di zaman modern. Siswa menganggap gurunya adalah guru yang mengajarnya di kelas. Sedangkan guru yang tidak mengajajarnya itu bukan gurunya. Harusnya pada diri siswa ditanamkan untuk tidak membedakan guru (menghargai dan toleran), karena semua guru yang ada di sekolah baik yang mengajarnya di kelas maupun guru yang tidak mengajarnya di kelas adalah guru mereka semua. Siswa beranggapan guru bisa menyenangkan hati mereka (seperti guru yang sering terlambat/izin/berkepentingan) adalah guru favorit, sedangkan guru yang idealis disebut sebagai guru killer, padahal semestinya guru yang idealis itulah yang seharusnya menjadi guru yang favorit.

Mata pelajaran sejarah di sekolah sering dianggap sebagai mata pelajaran yang membosankan dan kurang mendapat perhatian oleh pembuat kebijakan. Setiap peristiwa yang sudah terjadi dan dipelajari dibiarkan saja, tidak melekat dalam jiwa. Peristiwa sejarah yang dipelajari hanya pengalaman romantis dan heroik di masa lalu saja, lebih miris lagi termarginalkan dalam sisi sejarah kehidupan kita. Berawal dari cara pandang seperti itulah maka nilai-nilai sejarah tidak pernah melekat di hati peserta didik. Nilai-nilai sejarah tidak dijadikan pedoman untuk hidup, melainkan hanyalah retorika belaka, hafalan fakta dan konsep yang sangat kering dan pada akhirnya melemahkan jati diri dan identitas bangsanya.

Pelajaran sejarah merupakan bagian yang tidak terpisahkan dalam pembentukan watak dan peradaban yang bermartabat, berkepribadian bagi generasi muda. Pelajaran sejarah juga membangun memori kolektif sebagai bangsa untuk mengenal bangsanya dan membangun rasa persatuan dan kesatuan dan cinta tanah air (Kementrian Pendidikan dan Kebudayaan, 2013).

Kurikulum 2013 telah dirancang untuk membentuk manusia Indonesia yang memiliki kecakapan hidup yang dituntut oleh karakteristik kehidupan manusia abad 21. Kemampuan berfikir kritis dalam menyelesaikan masalah, kreatif dan inovatif (terbentuk karena karakter cerdas), kepemimpinan yang bertanggungjawab, dan berkontribusi dalam mewujudkan kehidupan umat manusia yang bermanfaat dan saling menghargai (Kebudayaan, 2017).

Mata pelajaran sejarah peminatan kelas $X$ merupakan salah satu mata pelajaran yang bisa dijadikan sebagai media untuk mewujudkan manusia Indonesia yang berkecakapan hidup abad 21. Oleh karena itu pembelajaran sejarah perlu digali dan dikembangkan secara mendalam, terutama untuk 
menemukan dan menginternalisasi nilai karakter apa saja yang terkandung dalam materi pelajaran sejarah peminatan kelas $X$.

\section{Pembahasan}

Nawacita pemerintahan Jokowi-Jusuf Kalla salah satunya adalah melakukan revolusi mental melalui kebijakan penataan kembali kurikulum pendidikan Nasional. Pendidikan adalah ussaha sadar untuk menyiapkan peserta didik melalui kegiatan bimbingan, pengajaran dan/atau latihan bagi peranannya dimasa yang akan datang. Pendidikan mempunyai peran strategis dalam upaya meningkatkan kualitas sumber daya manusia. Posisi yang strategis tersebut dapat tercapai apabila pendidikan yang dilaksanakan berkualitas.

Menurut Khan (2010) gagasan dasar tentang pendidikan karakter secara umum sesungguhnya bukan suatu hal yang baru bagi pembentukan watak generasi muda di Indonesia. Tokoh pendidikan Modern Indonesia tempo dulu yang dikenal seperti R.A Kartini, Ki Hajar Dewantoro, Soekarno, Hatta, Tan Malaka, Moh. Natsir telah berdaya upaya menerapkan semangat pendidikan karakter sebagai sarana untuk membentuk watak dan identitas (jati diri) bangsa Indonesia. Inilah cita-cita besar mereka dalam menggembleng rakyat Indonesia, membangun karakter bangsa untuk meraih Indonesia merdeka.

Hampir semua mata pelajaran saat ini mengevaluasi kompetensi pengetahuan, sedangkan evaluasi karakter (sikap) belum dikelola secara menyeluruh dan sungguh-sungguh. Proses pembelajaran akan berhasil manakala siswa mempunyai motivasi dalam belajar. Oleh sebab itu guru perlu menumbuhkan motivasi belajar siswa. Untuk memperoleh hasil belajar yang optimal, guru dituntut kreatif membangkitkan motivasi belajar siswa, sehingga terbentuk prilaku belajar siswa yang berkarakter (Sudrajat, 2015).

Tauladan kepahlawanan dapat diambil dari nilai-nilai luhur karakter bangsa seperti; disiplin, jujur, cinta tanah air, semangat kebangsaan (patriotisme,) kerja keras, mandiri, menghargai prestasi, tanggungjawab, peduli lingkungan, dan lain-lain. Ada 18 karakter mendasar yang terdapat dalam diri generasi muda yang harus dikembangkan berdasarkan nilai-nilai budaya untuk membentuk daya saing dan karakter bangsa meliputi hal-hal berikut; religius, jujur, toleran, disiplin, kerja keras, kreatif, mandiri, demokratis, rasa ingin tahu, nasionalisme, cinta tanah air, menghargai prestasi, bersahabat, komunikatif, peduli lingkungan, peduli sosial, tanggungjawab . Diantara 18 karakter generasi muda tersebut, terdapat dua karakter yang lebih mendasar yaitu, semangat kebangsaan (nasionalisme) dan cinta tanah air (patriotisme). Apabila generasi muda telah memiliki karakter nasionalisme dan patriotisme dengan baik, maka 
jenis karakter bangsa lainnya dengan sendirinya akan tercipta menjadi baik pula.

Strategi pembinaan karakter perlu didukung oleh tiga tiga pusat pendidikan, yakni orang tua, sekolah, dan lingkungan. Dalam konteks tersebut, budaya paternalistik bisa dijadikan acuan, yakni orang yang lebih tua disegani oleh yang lebih muda. Melalui peran orang tua dan guru yang berwibawa pendidikan karakter dapat ditanamkan (Khan, 2010).

Menurut Undri (2015), salah satu elemen yang memiliki posisi penting dalam penanaman nilai karakter dalam belajar sejarah adalah sumber daya manusia dalam bidang kesejarahan. Sumber daya ini terdiri dari guru sejarah, peneliti sejarah, juru peliharaan objek sejarah serta pramuwisata yang bergerak di bidang sejarah yang menjadi "corong” untuk menjelaskan informasi objek sejarah.

Kurikulum sejarah kelas $\mathrm{X}$ kelompok peminatan ilmu pengetahuan sosial berdasarkan peraturan menteri pendidikan dan kebudayaan republik Indonesia Nomor 24 Tahun 2016 mencakup beberapa kompetensi dasar (kognitif/pengetahuan), keterampilan sebagai berikut.

\section{Kompetensi Dasar}

3.1 Menganalisis kehidupan manusia dalam ruang dan waktu

3.2 Menganalisis kehidupan manusia dalam perubahan dan keberlanjutan

3.3 Menganalisis keterkaitan peristiwa sejarah tentang manusia di masa lalu untuk kehidupan masa kini

3.4 Menganalisis sejarah sebagai ilmu, peristiwa, kisah dan seni

3.5 Menganalisis cara berfikir diakronik dan sinkronik dalam karya sejarah

3.6 Mengevaluasi kelebihan dan kekurangan berbagai bentuk/jenis
4.1 Menyajikan hasil kajian tentang keterkaitan kehidupan manusia dalam ruang dan waktu dalam bentuk tulisan dan/ media lain

4.2 Menyajikan hasil telaah dalam bentuk tertulis tentang keterkaitan kehidupan manusia dalam perubahan dan keberlanjutan

4.3 Membuat tulisan tentang hasil kajian mengenai keterkaitan kehidupan masa lalu untuk kehidupan masa kini

4.4 Menyajikan hasil telaah tentang sejarah sebagai ilmu, peristiwa, kisah dan seni dalam bentuk tulisan dan/ atau media lain

4.5 Menyajikan hasil telaah tentang penerapan cara berfikir diakronik dan sinkronik dalam karya sejarah melalui tulisan dan/atau media lain

4.6 Menyajikan hasil evaluasi kelebihan dan kekurangan berbagai bentuk/jenis sumber sejarah 
Setya Ningsih

Menumbuhkan Pendidikan Karakter Melalui Pendalaman Materi Sejarah Peminatan Kelas X Sma

sumber sejarah (artefak, fosil, tekstual, non tekstual, kebenda an, visual, audio visual, tradisi lisan)

3.7 Memahami langkah-langkah penelitian sejarah (heuristik, kritik/verifikasi, interpretasi/eksplanasi, dan penulisan sejarah)

3.8 Menganalisis ciri-ciri dari historiografi tradisional, colonial, dan modern

3.9 Menganalisis persamaan dan perbedaan antara manusia purba Indonesia dan dunia dengan manusia modern dalam aspek fisik dan nonfisik

3.10 Menganalisis kehidupan awal manusia Indonesia dalam aspek kepercayaan

social, budaya, ekonomi, dan teknologi serta pengaruh dalam kehidupan masa kini

3.11 Menganalisis peradaban awal dunia serta keterkaitannya dengan peradaban masa kini pada aspek lingkungan, hukum, kepercayaan, pemerintahan, dan sosial (artefak, fosil, tekstual, nontekstual, kebendaan, visual, audiovisual, tradisi lisan) dalam bentuk tulisan dan/atau media lain

4.7 Menerapkan langkah-langkah penelitian sejarah (heuristik, kritik/verifikasi, interprestasi/eksplanasi dan penulisan sejarah yang ada di sekitarnya.

4.8 Menyajikan hasil kajian ciri-ciri historiografi tradisional, kolonial, dan modern dalam bentuk tulisan dan/atau media lain

4.9 Menyajikan hasil analisis mengenai persamaan dan perbedaan antara manusia purba Indonesia dan dunia dengan manusia modern dalam aspek fisik dan nonfisik dalam bentuk tulisan dan/atau media lain

4.10 Menarik kesimpulan dari hasil analisis mengenai keterkaitan kehidupan awal manusia Indonesia pada aspek kepercayaan, sosial, budaya, ekonomi, dan teknologi, serta pengaruhnya dalam kehidupan masa kini dalam bentuk tulisan dan/atau media lain

4.11 Menyajikan analisis peradaban awal dunia serta keterkaitannya dengan peradaban masa kini pada aspek lingkungan, hukum, kepercayaan, pemerintahan, dan social dalam bentuk tulisan dan/atau media lain

Tabel 1: Kompetensi Dasar (Kognitif/Pengetahuan dan Keterampilan) Kelas X SMA Sejarah Peminatan

Sumber: Kementrian Pendidikan dan Kebudayaan, (2016)

Sejarah dan manusia tidak bisa terpisahkan satu sama lain, bahkan manusia dan sejarah merupakan suatu dwitunggal. Sejarah mengutamakan kajian tentang manusia-manusia yang memiliki aksi dari pada mereka yang terdiam dan menunggu. Sejarah mengkaji berbagai aksi manusia di sepanjang zaman. Manusia Hidup dalam ruang dan waktu. Ruang dan waktu merupakan panggung kehidupan manusia. Segala yang dilakukan manusia tidak dapat dilepaskan dari dimensi ruang dan waktu (Darussalam, 2014).

Pembentukan karakter-karakter tertentu bagi siswa pada umumnya telah ada dalam materi pembelajaran kelas $X$ sejarah peminatan. Pada materi pelajaran tentang Manusia dan Sejarah ditekankan bahwa peran manusia dalam sejarah layaknya pemeran utama dalam drama. Manusia sebagai penggerak sejarah mengandung makna tentang berartinya seluruh aktivitas manusia dalam ruang dan waktu. Maka dari itu manusia harus melakukan aktivitas yang bermanfaat dan bertanggungjawab. 
Mohamad Hatta adalah salah satu tokoh sejarah yang menunjukkan tanggungjawab untuk negeri tercinta Indonesia. Nilai-nilai keteladanan yang patut dicontoh dari seorang Hatta adalah sikap sederhana, jujur, adil dan mencintai buku. Mohammad Hatta merupakan tokoh proklamasi yang hidup dengan penuh kesederhanaan. Kesederhanaan beliau layak dicontoh dalam kehidupan siswa agar menjadi pribadi yang siap menerima keadaan. Adapun nilai-nilai lain yang bisa diambil adalah dari lingkungan sekitar. Belajar sejarah tidak hanya dari tokoh tapi bisa juga dari lingkungan (Karima, 2019).

Dalam novel berjudul Hatta Aku Datang Karena Sejarah, pada bab pengakuan, Hatta mengatakan ia sangat mencintai buku-bukunya, sampai debupun tidak boleh menempel dibukunya (Sutanto, 2018). Apabila siswa dapat mencontoh sikap keteladanan Hatta yang rajin membaca buku maka siswa tentu memiliki wawasan luas dan memperoleh hasil belajar yang memuaskan. Hasil belajar karena usaha sendiri, tentu lebih memuaskan daripada hasil belajar dari prilaku tidak jujur atau bertanya kepada teman saat mengerjakan ujian atau berbuat kecurangan lainnya.

Materi pada kompetensi dasar menganalisis kehidupan manusia dalam ruang dan waktu, siswa diharapkan dapat bertanggngjawab dengan segala keputusan atau perbuatan yang dilakukannya. Hal ini dapat dirasakan oleh siswa apabila siswa menghayati hakekat manusia sebagai mahkluk yang menyejarah, yang setiap perbuatan dan keputusannya dimasa kini akan memengaruhi kehidupan mendatang.

Dengan menganalisis cara berpikir diakronik dan sinkronik dalam karya sejarah, siswa diharapkan dapat menerapkan sikap disiplin dalam kehidupan sehari-hari. Hal ini dikarenakan cara berpikir diakronik dan sinkronik mengajarkan siswa untuk lebih teliti dalam mengamati rentetan peristiwa sejarah dari waktu ke waktu (konsep diakronik) dan dari berbagai aspek, misalnya aspek politik, sosial, dan budaya (konsep sinkronik).

Materi pelajaran tentang Penelitian Sejarah dan Historiografi, karakter yang dikembangkan adalah disiplin dan jujur (sudah tercantum pula pada materi sebelumnya). Dengan cara mengevaluasi kelebihan dan kekurangan berbagai bentuk/ jenis sumber sejarah (artefak, fosil, tekstual, nontekstual, kebendaan, visual, audiovisual, dan tradisi lisan), siswa diharapkan dapat mengembangkan sikap disiplin dan jujur. Sikap disiplin dapat dikembangkan karena dalam menganalisis sumber sejarah diperlukan ketelitian. Hal ini karena sumber sejarah, terutama tradisi lisan sering dimasukkan unsur mitos. Sikap jujur dapat dikembangkan karena dalam sumber sejarah banyak terdapat interpretasi atau pendapat dari si empunya cerita. 
Memahami langkah-langkah penelitian sejarah (heuristik, kritik/ verifikasi, interpretasi/eksplanasi, dan penulisan sejarah), siswa secara tidak langsung diharapkan dapat memahami pentingnya proses, ketekunan, kerja keras, komitmen pribadi untuk mencapai sesuatu. Kesemuanya itu tentu saja diperlukan sikap proaktif dan responsif siswa.

Dengan menganlisis ciri-ciri historiografi tradisional, kolonial dan modern, siswa diharapkan dapat mengembangkan sikap tanggung jawab. Hal ini karena dalam perkembangan historiografi dapat dilihat adanya kepentingan politik. Seseorang peneliti sejarah seharusnya memiliki sikap tanggung jawab intelektual dalam diri sendiri untuk berani mengungkapkan fakta sejarah.

Materi pelajaran mengenai Manusia Indonesia, Corak Kehidupan, dan Hasil-Hasil Budaya Pada Masa Praaksara, karakter dikembangkan adalah menghargai budaya bangsa. Dengan menganalisis keterkaitan manusia purba Indonsia dan dunia dengan manusia modern dalam aspek fisik dan budaya, siswa diharapkan mampu mengembangkan sikap menghargai budaya bangsa. Hal ini karena nenek moyang bangsa Indonesia memberikan sumbangan kebudayaan serta peradaban yang khas dan bermakna. Apa yang telah diwariskan oleh nenek moyang telah membentuk identitas dan kepribadian bangsa Indonesia. Sudah sepantasnya siswa sebagai generasi muda bangsa menghargai kebudayaan bangsa sendiri beserta tradisi-tradisi dan falsafah hidup bangsa serta tidak mudah tergiur oleh kebudayaan asing yang potensial merusak jati diri atau identitas bangsa Indonesia. Bangsa yang besar adalah bangsa yang memiliki kepribadian dan identitas yang khas.

Dengan menganalisis keterkaitan kehidupan awal manusia Indonesia di bidang kepercayaan, sosial, budaya, ekonomi, dan teknologi serta pengaruhnya dalam kehidupan masa kini, siswa diharapkan dapat mengembangkan sikap kreatif. Sifat kreatif dapat dibangun dengan mempelajari kehidupan masyarakat praaksara yang telah menciptakan berbagai hasil kebudayaan. Hasil kebudayaan itu bahkan beberapa masih bertahan hingga kini.

Kreativitas masyarakat prasejarah di Indonesia terbentuk karena mampu mereka mampu merespon lingkungan, misalnya tulisan dan perhitungan matematika berkembang karena dibutuhkan dalam menunjang kegiatan perdagangan. Sikap ini dapat ditiru saat ini dengan melakukan inovasi dalam bidang ipteks. Dengan menganalisis keterkaitan peradaban awal dunia dengan peradaban masa kini siswa mampu menghargai segala perbedaan dalam masyarakat, siswa dapat belajar toleran. Sikap saling menghargai sangat dibutuhkan saat ini untuk menghindari konflik-konflik sosial yang mengancam NKRI. 
Upaya mengoperasionalkan nilai nilai karakter dan nilai sejarah adalah melalui pembelajaran di sekolah. Sekolah merupakan preserver dan transmitter dari culture hiratage merupakan alat untuk transfer budaya (Undri, 2015). Cara-cara yang dapat ditempuh antara lain; pertama, materi pelajaran yang dikembangkan dalam pembelajaran sejarah harus memiliki pendekatan multikultural, karena secara realistik objektif, masyarakat Indonesia pada umumnya adalah masyarakat plural baik secara suku, agama, etnis, budaya, pekerjaan, dll.

Kedua materi pelajaran sejarah harus mengeksplorasi materi sejarah lokal yang bersumber dari peninggalan-peninggalan sejarah di daerah. Pembelajaran sejarah lokal mampu mengantarkan siswa untuk mencintai daerah dalam mewujudkan ketahanan daerah. Ketahanan daerah merupakan kemampuan suatu daerah yang ditunjukkan oleh kemampuan warganya untuk menata diri sesuai konsep yang diyakini kebenaraannya dengan jiwa yang tangguh, semangat yang tinggi serta memanfaatkan alam secara bijaksana.

Ketiga, penyajian materi pelajaran sejarah dilakukan secara kontekstual. Artinya sajian materi pelajaran sejarah dikaitkan dengan konteks peristiwa sejarah yang terjadi saat ini. Keempat, materi pelajaran sejarah harus memiliki misi membentuk karakter generasi bangsa. Hal ini dilakukan dengan tujuan agar materi sejarah mampu membangun jati diri bangsa. Nilai-nilai dikembangkan dari peristiwa sejarah harus tertanam dalam diri siswa. Banyak peristiwa sejarah lokal maupun nasional yang bernilai edukatif, inspiratif dan rekreatif dan perlu diajarkan kepada siswa.

Penanaman nilai-nilai karakter melalui materi pelajaran sejarah tidak terlepas dari peran utama para guru sejarah. Guru sejarah harus mampu menciptakan suasana pembelajaran sejarah yang kreatif, menggunakan metode pembelajaran berorientasi pengembangan kemampuan berpikir kritis, pemecahan masalah, komunikasi dan kolaborasi untuk menepis anggapan bahwa pelajaran sejarah membosankan. Guru yang menerapkan berbagai metode pembelajaran, seperti Role Playing, Problem Based Learning, Project, STAD, (Student team achievement discussion), Discovery Learning, dll. Semua metode tersebut telah sering disarankan kepada guru-guru dalam pembelajaran kurikulum 2013. Tujuannya agar pembelajaran berpusat pada siswa (student center) dan untuk mencapai kecakapan abad 21.

Sosok guru adalah sosok panutan dan teladan dalam menyemai nilai-nilai karakter. Pendidikan karakter dalam materi pelajaran sejarah peminatan kelas $X$ SMA sangat tergantung pada sosok yang diteladani yaitu guru sejarah. Guru harus mengembangkan hubungan yang terbuka dan sinergis antara dirinya dan siswa di dalam kelas dan dengan seluruh komunitas sekolah. Guru harus 
mampu membangun lingkungan pembelajaran yang kondusif dengan mengapresiasi serta menghargai keunikan individu, memfasilitasi diskusi, dialog dalam pengambilan keputusan terhadap penyelesaian masalah. Guru Hebat harus berkarakter di setiap aktivitas untuk kemajuan anak bangsa.

Penanaman nilai-nilai karakter dapat melalui kegiatan kokurikuler dan ekstrakurikuler seperti kepramukan, Palang Merah Remaja (PMR), Organisasi Siswa Intra Sekolah (OSIS), olahraga, kesenian, dan lain sebagainya. Ekosistem dan budaya sekolah, tata kelola yang akuntabel, hubungan antar warga sekolah yang menjunjung tinggi kejujuran, harmonis, dan saling menghargi tidak kalah pentingnya juga pendidikan dalam keluarga dan masyarakat. Sangat dibutuhkan keselarasn antara pendidikan di sekolah dan di lingkungan keluarga serta masyarakat agar penumbuhan nilai-nilai karakter dapat dilaksanakan secara optimal.

\section{Kesimpulan}

Materi sejarah sangat kaya dengan unsur-unsur nilai karakter bangsa. Karakter generasi muda dapat dibentuk dengan mendalami dan mempelajari sejarah bangsa dan menemukan nilai-nilai karakter yang ditunjukkan oleh tokoh sejarah, para pahlawan bangsa. Sebagai generasi penerus bangsa, siswa dituntut mampu mempertanggungjwabkan dari seluruh aktivitas mereka dalam ruang dan waktu sebagai bentuk meneladani nilai-nilai karakter para tokoh sejarah bangsa.

Guru adalah sosok utama ketauladanan bagi siswa, nilai-nilai karakter dapat diimplementasikan dengan meneladani guru yang berkarakter di setiap ruang geraknya. Penggiat sejarah (guru, siswa, keluarga, masyarakat, peneliti sejarah, maupun pramuwisata) diharapkan dapat bertanggungjawab atas segala aktivitasnya agar dapat dijadikan teladan yang baik untuk generasi masa yang akan datang.

\section{Daftar Rujukan}

Darussalam, S. F. dan. (2014). Sejarah untuk SMA/MA Kelas X Kelompok Peminatan Ilmu-IImu Sosial. Bandung: Yrama Widya.

Karima, E. M. (2019). Modul Berbsis Green History untuk Pembelajaran Sejarah di Sekolah Menengah Atas. Diakronika, 18 (2), 45-57.

Kebudayaan, D. P. S. M. A. D. P. D. dan M. K. P. dan. (2017). Materi Umum Kebijakan dan Dinamika Perkembangan Kurikulum. Jakarta: Direktorat 
Pembinaan Sekolah Menengah Atas Dirjen Pendidikan Dasar dan Menengah Kementrian Pendidikan dan Kebudayaan.

Kementrian Pendidikan dan Kebudayaan. (2013). Buku Panduan Guru kelas X SMA/MA/SMK/MAK, Edisi revisi, 2014). Jakarta: Kementrian Pendidikan dan Kebudayaan.

Khan, Y. (2010). Pendidikan karakter berbasis potensi diri. Yogyakarta: Pelangi Publishing.

Ki Hajar Dewantara. (1962). Materi Umum Kebijakan dan Dinamika Perkembangan Kurikulum. Jakarta: Badan Penelitian dan Pengembangan Kemendikbud RI.

Sudrajat, A. (2015). Peran Guru Sebagai Motivator.

Sutanto, S. (2018). Hatta. Mizan Qanita.

Undri. (2015). Pelestarian Nilai Sejarah, Sumberdaya Bidang Kesejarahan dan Pembelajaran di Sekolah. Pekanbaru. 